\title{
IL12RB1 wt Allele
}

National Cancer Institute

\section{Source}

National Cancer Institute. IL12RB1 wt Allele. NCI Thesaurus. Code C52044.

Human IL12RB1 wild-type allele is located in the vicinity of 19p13.1 and is approximately $74 \mathrm{~kb}$ in length. This allele, which encodes interleukin-12 receptor beta-1 chain protein, is involved in IL12 signal transduction. Heritable defects in the IL12RB1 gene are a cause of susceptibility to mycobacterial disease. 